\title{
Nuclear DNA content in the subgenus Coffea (Rubiaceae): inter- and intra-specific variation in African species
}

\author{
J. Cros, M.C. Combes, N. Chabrillange, C. Duperray, \\ A. Monnot des Angles, and S. Hamon
}

\begin{abstract}
Flow cytometry has been used to estimate nuclear DNA content of 13 Coffea species (Rubiaceac) native to Africa. Twelve diploid $(2 n=22)$ and one tetraploid (C. arabica. $2 n=44)$ species were investigated. Isolated nuclei from 77 genotypes were stained with propidium iodide (PI: not base specific). Thirty-nine genotypes were stained with 4',6-diamidino-2-phenylindole (DAPI; AT specific). Nuclear DNA content ( $2 \mathrm{C}$ values). estimated with PI. ranged from 0.95 to $1.78 \mathrm{pg}$. By aggregative clustering. three groups of accessions with increasing DNA content were identified. Three species. namely $C$. sessiliflora, $C$. racemosa, and $C$. pseudozanguebariae, had a low DNA content $(0.90-1.30 \mathrm{pg})$. Three species, namely $C$. eugenioides. $C$. stenophylla, and $C$. sp. F, were exclusively found in the intermediate group $(1.31-1.60 \mathrm{pg})$. The remaining species were distributed between the intermediate group and the last group $(1.61-1.80 \mathrm{pg})$. The values determined for the Coffea species are compared, inter- and intra-specifically, to those of other angiosperm species. The observed differences are discussed according to the ecogeographic origin of the species. their phenological characteristics, and the fertility of the $F_{1}$ interspecific hybrids.
\end{abstract}

Key words: Africa, Coffer, flow cytometry, nuclear DNA content, genome evolution.

\begin{abstract}
Résumé : La cytométrie en flux a été utilisée pour estimer la quantité d'ADN nucléaire chez 13 espèces de Coffea (Rubiaceae) originaires d’Afrique. Douze espèces diploïdes $(2 n=22)$ et l'espèce tétraplö̈de C. arabica $(2 n=44)$ ont été analysées. Pour 77 génotypes, des populations de noyaux isolés ont été colorées par l'iodure de propidium (IP: non spécifique des bases). Pour trente neuf génotypes, le 4'.6-diamidino-2-phenylindole (DAPI; AT spécifique) a été également utilisé. Les quantités 2C d'ADN nucléaire, estimées avec l'IP, oscillent entre 0.95 et $1.78 \mathrm{pg}$. Trois groupes correspondant à des quantités croissantes d ADN ont été mis en évidence. Les trois espèces $C$. sessiliflora. $C$. racemosa et C. pseudozanguebariae se classent dans le groupe des plus petites valeurs (groupe $1: 0,90$ à $1,30 \mathrm{pg}$ ). Les tröis espèces $C$. eugenioides, $C$. stenophylla et $C$. sp. F. se rangent uniquement dans le groupe des valcurs intermédiaires (groupe $2: 1.31$ à $1.60 \mathrm{pg}$ ). Les autres especes se repartissent entre le groupe 2 et le groupe des plus hautes valeurs (groupe $3: 1.61$ a $1.80 \mathrm{pg}$ ). Les valeurs déterminées pour les espèces de Coffea. sont comparées at niveau intra- et inter-spécifique à celles dautres angiospermes. Les différences observées sont discutées en fonction de l'origine éco-géographique des espèces. leurs caractéristiques phénologiques et la fertilité de leurs hybrides $F_{1}$ interspécifiques.
\end{abstract}

Mots clès: Afrique. Coffea. cytométrie en flux. quantité d'ADN par noyau. evolution des genomes.

\section{Introduction}

Large variation in nuclear DNA content, from 1 to more than $125 \mathrm{pg}$ per diploid nucleus, has been reported among angio-

Received April 22, 1994.

J. Cros, M.C. Combes, N. Chabrillange and S. Hamon Institut Français de Recherche Scientifique pour le Développement en Coopération. Laboratoire de ressources génétiques et amélioration des plantes tropicales.

BP 3045-34032. Montpellier. France.

C. Duperray Institut national de la santé et de la recherche médicale, Unite 291. Service commun de cytométrie en flux. 99. rue P. Villa, 34090 Montpellier. France.

A. Monnot des Angles Chemunex, 41, rue du 11 novembre. 94700. Maison Alfort. France. sperms (Price 1988). Until recently. most DNA contents were determined by Feulgen microspectrophotometry of root tip mitoses (Bennet and Smith 1991). Since the introduction of flow cytometry. DNA content can be determined more easily using fluorochromes after leaf chopping. protoplast lysis, or nuclei isolation (Arumuganathan and Earle 1991a: Dolezel 1991: Ulrich and Ulrich 1991; Dolezel et al. 1992). In the Coffea genus, the only reported value, namely $-1.67 \mathrm{pg}$ of DNA per nucleus, is that of one genotype of $C$. canephora (Marie and Brown 1993).

Current commercial green coffee production relies on two species. $C$. arabica $2 n=44$, autogamous. cultivated at altitude mainly in central and south America) and $C$. canephora $(2 n=22$. allogamous. cultivated in lowlands mainly in Africa and Asia). Wild species present great genetic diversity structured in three biogengraphic areas: Madagascan floristic 
region (Charrier 1978), east Africa (Bridson and Verdcourt 1988), and the Guinea-Congo region (Chevalier 1947). Some species have agronomic characteristics that could be of value to coffee breeders (Berthaud and Charrier 1988). A large number could be intercrossed (Louarn 1993).

In the study reported here, we evaluated the total nuclear DNA content, using isolated nuclei stained with propidium iodide (PI; not base pair specific), of a representative panel of African Coffea species. Nuclei of several genotypes within each species were also stained with 4',6-diamidino-2-phenylindole (DAPI; AT specific). Results are discussed according to the ecogeographic origin of the species, their phenological characteristics, and the fertility of their $F_{1}$ interspecific hybrids.

\section{Materials and methods}

\section{Plant cultivation}

Coffee plants were grown from seeds in a greenhouse with a tropical climate $\left(24^{\circ} \mathrm{C}\right.$ during the day, $18^{\circ} \mathrm{C}$ at night, relative humidity of $70 \%$ ). Leaves were collected at the same time from the second node from the apex of the main stem or branches. Leaves were used fresh or frozen in liquid nitrogen and stored at $-80^{\circ} \mathrm{C}$ before processing.

\section{Species and genotypes}

Seventy-seven genotypes belonging to 13 African species were analyzed. It was possible to stain with both fluorochromes in only a few genotypes because of the small size of the plants, the availability of leaves, and the need to isolate nuclei for PI staining. In the following list, the number of genotypes per species is given in parentheses: the first number corresponds to genotypes stained with PI, the second to those stained with DAPI. Seven species were native to the Guinea-Congo region: $C$. brevipes $(8,3), C$. canephora $(11,3), C$. congensis $(9,3), C$. humilis $(5,2), C$. liberica $(8,8), C$. sp. Moloundou $(3,2)$, and $C$. stenophylla $(6,3)$. Six species were native to eastern Africa: $C$. eugenoides $(3,2)$, C. pseudozanguebariae $(5,2), C$. sessiliflora $(6,2), C$. racemosa $(4,2), C$. sp. F Bridson $(3,3), C$. arabica $(6,4)$. Except for $C$. arabica $(2 n=4 x=44)$, all other species were diploids $(2 n=2 x=22)$.

\section{Nuclei preparation}

Preliminary experiments were performed using thinly sliced leaves in different lysis buffers. Unpurified nuclei suspensions were stained with PI according to Aramuganathan and Earle (1991a). Results were heterogeneous in quality, with high CV peaks. Nuclei purification protocols have been tried in an attempt to avoid the problems associated with low penetration of DNA-specific fluorochrome (Dolezel 1991) and improve the quality of the results. On the contrary, preliminary results with DAPI showed that the use of flow cytometry on unpurified nuclei suspensions gave peaks of high resolution and low CV. As already noted by Marie and Brown (1993), the analysis of unpurified nuclei suspensions often seems more convenient with UV-excited dyes such as Hoechst bisbenzimidine or DAPI. Therefore, in this study the experiments using PI were performed on purified nuclei suspensions, and the experiments using DAPI intercalent were on unpurified nuclei suspensions.
The preparation of unpurified nuclei suspension was adapted from Galbraith et al. (1983). Crude samples containing nuclei were prepared from leaf material (approx. $500 \mathrm{mg}$ ) by chopping with a sharp razor blade in $1 \mathrm{~mL}$ of Chemunex commercial buffer R09-220-500 (Chemunex, Maison Alfort, France). The suspended cell constituents were stained for 20 min using DAPI at a final concentration of $10 \mu \mathrm{g} / \mathrm{mL}$. Before analysis, the suspension was filtered through a nylon membrane of $17-\mu \mathrm{m}$ mesh size to remove large debris.

Partially purified nuclei suspension was prepared using three different sucrose buffers. Fresh leaves were ground to a fine powder using liquid nitrogen, mixed with buffer $\mathrm{A}$ (0.4 M sucrose, $0.05 \mathrm{M}$ Tris, $2 \mathrm{mM} \mathrm{CaCl}_{2}, 0.4 \% \beta$-mercaptoethanol) and filtered through $50-\mu \mathrm{m}$ Blutex membrane (Scrynel, Rüschlikon, Switzerland). The solution was centrifuged at $3000 \times g$ and $4^{\circ} \mathrm{C}$ for $15 \mathrm{~min}$. The pellets were resuspended in buffer $\mathrm{B}(0.25 \mathrm{M}$ sucrose, $0.05 \mathrm{M}$ Tris, $2 \mathrm{mM}$ $\mathrm{CaCl}_{2}$ ) and centrifuged again at $3000 \times \mathrm{g}$ and $4^{\circ} \mathrm{C}$ for $15 \mathrm{~min}$. The second pellet was carefully mixed with $5 \mathrm{~mL}$ of buffer $\mathrm{B}$ and $20 \mathrm{~mL}$ of buffer $\mathrm{C}$ ( $2 \mathrm{M}$ sucrose, $0.05 \mathrm{M}$ Tris, $2 \mathrm{mM} \mathrm{CaCl}_{2}$ ) and centrifuged at $16000 \times g$ and $4^{\circ} \mathrm{C}$ for 45 min. The last nuclei pellet could be stored at $-80^{\circ} \mathrm{C}$ for 1 week. Before analysis, $500 \mu \mathrm{L}$ of phosphate-buffered saline $\left(7.74 \times 10^{-2} \mathrm{M} \mathrm{Na}_{2} \mathrm{HPO}_{4}, 2.26 \times 10^{-2} \mathrm{M} \mathrm{NaH}_{2} \mathrm{PO}_{4}\right.$, $\mathrm{pH} 7.4$ ) was added to isolated nuclei and warmed to room temperature. The nuclei suspension was incubated for 5 min in PI at a final concentration of $160 \mu \mathrm{g} / \mathrm{mL}$.

\section{Apparatus}

Resuspended PI-stained nuclei were analyzed using a FAC-Scan flow cytometer (Becton Dickinson European, ErembodegemAalst, Belgium) equipped with an argon laser $(15 \mathrm{~mW})$ emitting at $488 \mathrm{~nm}$. The voltage of the photomultipliers was set at $550 \mathrm{~V}$. Five thousand nuclei were measured in each run.

DAPI-stained nuclei were analyzed using a CA-II flow cytometer (Partec Gmbh, Munster, Germany) equipped with a 100-W high-pressure mercury lamp for UV $360 \mathrm{~nm}$ excitation. Emission light was collected using a 420-nm long-pass filter.

\section{Reference samples}

With PI, under our experimental conditions, the $C$. arabica peak occurred near the $600-\mathrm{W}$ channel. Measurements were made on a linear scale. To estimate total nuclear content, rice nuclei (Oryza sativa type japonica, 2C $=1.2 \mathrm{pg}$; Bennett and Smith 1991) were used as calibration standards between each sample of Coffea. To estimate the total DNA content, we compared the mean position of the tested sample with the mean position of the calibration standard. According to Galbraith et al. (1983), the amount of nuclear DNA $=$ (mean position of the tested sample/mean position of the rice nuclei) $\times 1.2 \mathrm{pg}$. With DAPI, our standard was internal (Petunia hybrida, 2C $=2.85 \mathrm{pg}$; Marie and Brown 1993). Its peak was arbitrarily fixed on channel 100 on a logarithmic scale. The values measured were translated on a linear scale using a formula demonstrated by Chemunex (unpublished data). For 39 genotypes stained by both dyes it was possible to compare nuclear DNA content and fluorescence intensity observed after staining with DAPI (dependent on the nuclear DNA content and the genome base composition). 
Fig. 1. Peaks obtained for three samples of Coffea using two different stains. $(a-c)$ PI on isolated nuclei (see text) $(d-f)$ DAPI on unpurified nuclei and Petumia hybrida as internal standard.
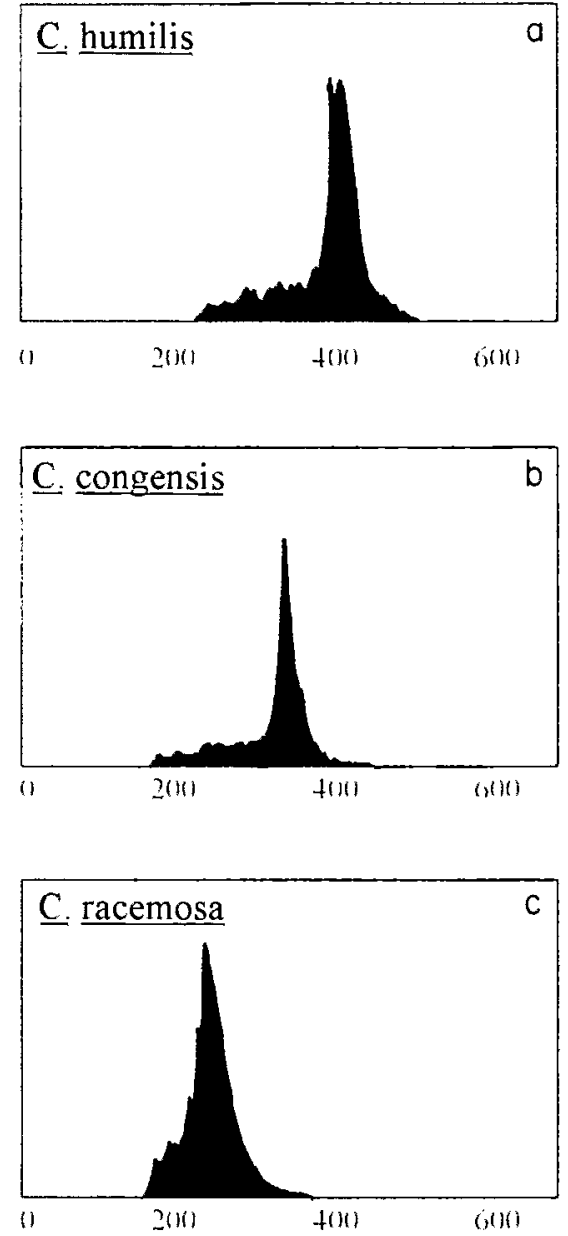

Relative fluoresconce measured

alter Pl staming (linear scale)
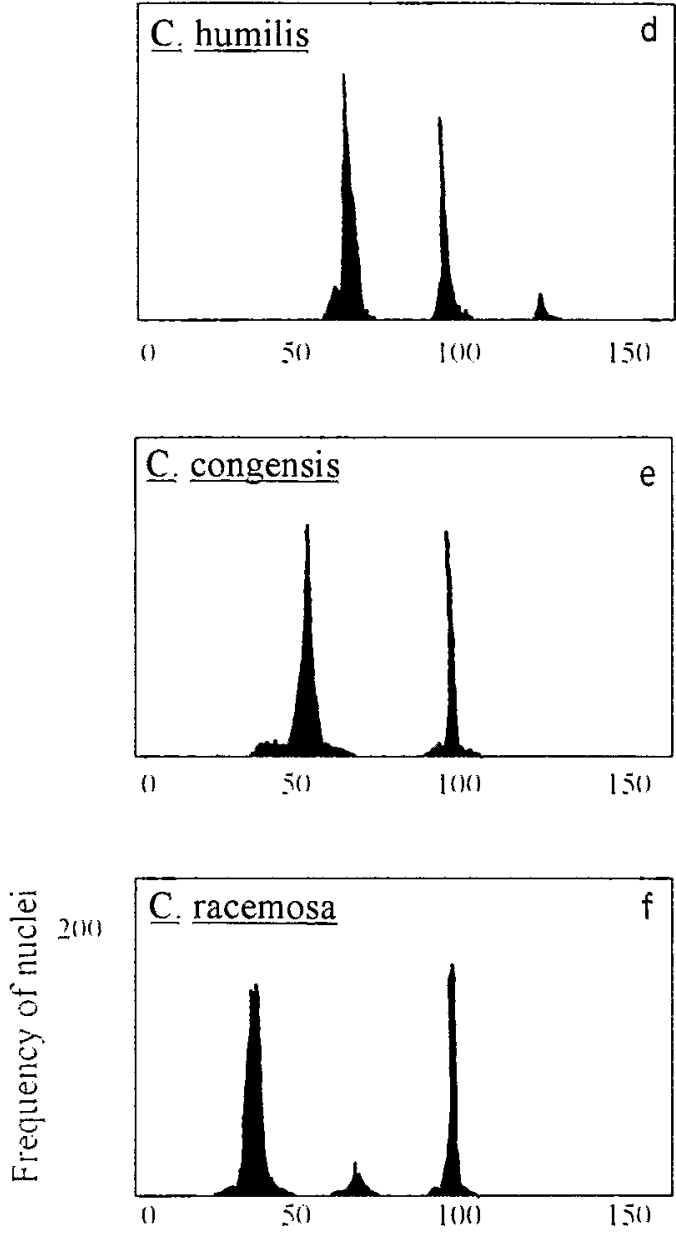

Relative fluorescence measured after DAPI staining (log scale)

Table 1. Nuclear DNA content of 13 Coffea species.

\begin{tabular}{lclcc}
\hline \multicolumn{1}{c}{ Species } & Ploidy & Biogeographic area & $\begin{array}{c}\text { DNA content } \\
\text { (pg per nucleus) }\end{array}$ & Aggregative group* \\
\hline C. arabica & $4 x$ & East Africa & $2.61 \pm 0.23$ & na \\
C. humilis & $2 x$ & Guinea-Congo region & $1.78 \pm 0.33$ & A \\
C. sp. moloundou & $2 x$ & Guinea-Congo region & $1.69 \pm 0.25$ & A-B \\
C. liberica & $2 x$ & Guinea-Congo region & $1.68 \pm 0.29$ & A-B \\
C. congensis & $2 x$ & Guinea-Congo region & $1.62 \pm 0.19$ & B \\
C. breviper & $2 x$ & Guinea-Congo region & $1.55 \pm 0.18$ & B \\
C. canephora & $2 x$ & Guinea-Congo region & $1.54 \pm 0.22$ & B \\
C. eugenioides & $2 x$ & East Africa & $1.39 \pm 0.12$ & B \\
C. stenophylla & $2 x$ & Guinea-Congo region & $1.35 \pm 0.12$ & B \\
C. sp. F & $2 x$ & East Africa & $1.33 \pm 0.02$ & B \\
C. pseudozanguebariae & $2 x$ & East Africa & $1.09 \pm 0.13$ & C \\
C. sessiliffora & $2 x$ & East Africa & $1.04 \pm 0.16$ & C \\
C. racemosa & $2 x$ & East Africa & $0.95 \pm 0.13$ & C \\
\hline
\end{tabular}

*A. B, and C indicate groups of values not significantly different at $P=0.05$ according to Newman and Keul's multiple range test. na. not included in the analysis. 
Fig. 2. Least squares regression analysis between PI and DAPI of mean values per species. The regression line $(r=0.95)$ passes through $(0,0)$; the slope $=33.5 \pm 2.1$ for $95 \%$ confidence.

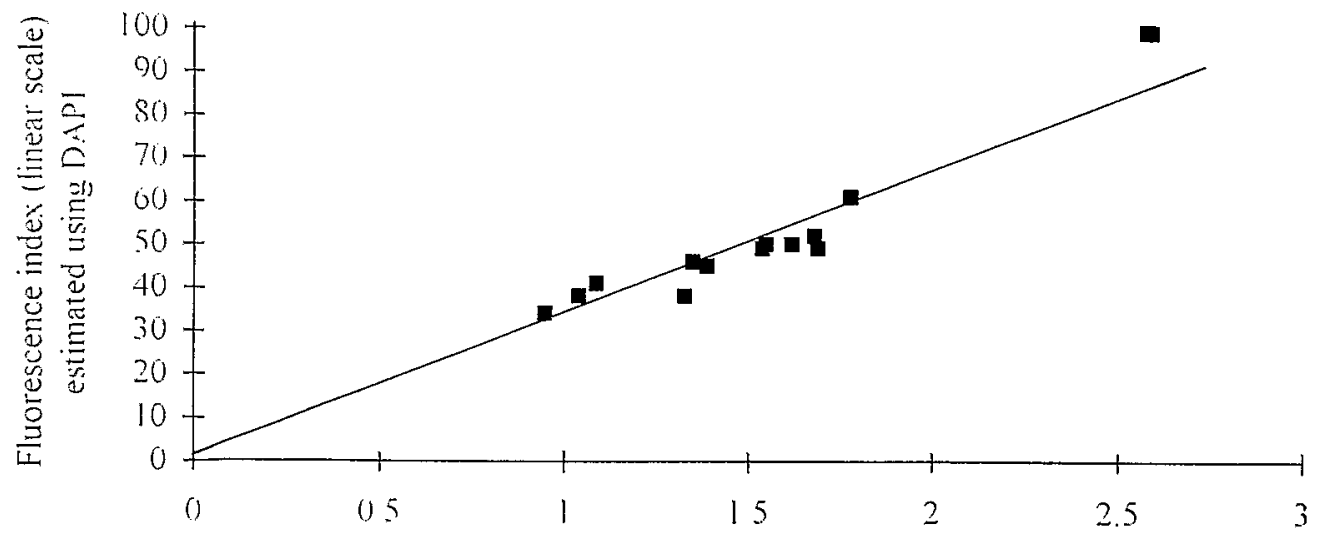

Nuclear DNA content (py) estimated using PI

\section{Results}

Figures $1 a-1 c$ show that high resolution of nuclear DNA content was achieved using laser flow cytometry and PI. Addition of sarkosyl ( $1.5 \%$ final) to the nuclei suspension, before addition of PI, improved the peak resolution. The sharp peak and low CV value indicate that the nuclei were well isolated and did not suffer significant damage during staining and analysis. Typically, CV values of 2.0 to 7.0 are obtained by this flow cytometric procedure. Using DAPI on unpurified nuclei suspensions, the simple chopping also provided reliable results (Figs. $1 d-1 f$ ).

The mean nuclear DNA contents of 13 Coffea species are listed in Table 1. Species names and biogeographic area are ordered according to the decreasing value of their mean nuclear DNA content. As expected, $C$. arabica (tetraploid) had the highest nuclear DNA content (2.61 pg per nucleus). For diploid Coffea species, nuclear DNA content ranged from $0.95 \mathrm{pg}$ (C. racemosa) to $1.78 \mathrm{pg}$ (C. humilis). Mean values for each species were compared to test significance using a Newman and Keul's multiple range test (Table 1). Three groups were distinguished: medium-high (groups A and A-B), medium (group B), and low nuclear DNA content (group $\mathrm{C}$ ). To test accessions grouping, a clustering analysis, using the minimum intragroup variance criteria, was performed on the individual values of the DNA content. As in Newman and Keul's test based on the mean values for the species, three groups with increasing DNA content were identified (Table 2): group 1 (DNA content $0.90-1.30 \mathrm{pg}$ ) comprised 14 genotypes of the three species $C$. sessiliflora, C. racemosa, and $C$. pseudozanguebariae; group 2 (DNA content $1.31-1.60 \mathrm{pg}$ ) included all genotypes of $C$. eugenioides, $C$. stenophylla, and $C$. sp. F, one genotype of $C$. pseudozanguebariae, and several genotypes of the six remaining species; and group 3 (DNA content $1.61-1.80 \mathrm{pg}$ ) comprised genotypes of $C$. humilis, C. sp. Moloundou, $C$. liberica, $C$. congensis, $C$. brevipes, and $C$. canephora. These species were not found in this group with equal frequency. Most genotypes of $C$. humilis and C. sp. Moloundou $(0.75-0.80)$ were found in group 3 , compared with onethird for $C$. canephora and $C$. brevipes $(0.37-0.36)$. These
Table 2. Frequency of distribution in aggregative groups obtained on the basis of the nuclear DNA content of 77 Coffea accessions.

\begin{tabular}{lccc}
\hline & \multicolumn{3}{c}{ Group } \\
\cline { 2 - 4 } \multicolumn{1}{c}{ Species } & 1 & 2 & 3 \\
\hline C. humilis & & 0.20 & 0.80 \\
C. sp. moloundou & & 0.25 & 0.75 \\
C. liberica & & 0.34 & 0.66 \\
C. congensis & & 0.38 & 0.62 \\
C. brevipes & & 0.63 & 0.37 \\
C. canephora & 0.64 & 0.36 \\
C. eugenioides & & 1.00 & \\
C. stenophylla & & 1.00 & \\
C. sp. F & & 1.00 & \\
C. pseudozanguebariae & 0.80 & 0.20 & \\
C. sessiliflora & 1.00 & & \\
C. racemosa & 1.00 & & \\
Limits of groups & & & \\
$\quad$ (in pg of DNA) & $0.90-1.30$ & $1.31-1.60$ & $1.61-1.80$ \\
\hline
\end{tabular}

NoTE: The aggregative analysis of individual values used the minimum intragroup variance criteria.

results suggest a structured level of difference between diploid Coffea species.

Calculated values (linear scale) of the fluorescence index using DAPI for diploid species ranged from 34 for $C$. racemosa to 61 for $C$. humilis. Figure 2 shows a least squares regression analysis performed on mean values for the species obtained with DAPI (AT specific) and mean nuclear DNA content per species estimated using PI. Estimations using these two dyes were well correlated $(r=0.95)$. This means that the percent AT for these species was not significantly different. The least squares regression line passes through a point not significantly different from zero. These results indicate that the nuclear DNA content, for a sample belong- 
ing to this representative set of Coffea species. could be estimated indirectly using DAPI staining of unpurified nuclei.

\section{Discussion}

\section{Coffea nuclear DNA content compared with other angiosperm species}

Marie and Brown (1993) reported a DNA content of $1.67 \mathrm{pg}$ per nucleus tor one genotype of C. cant?hora. which was the only available value in the literature. Our data are consistent with this estimation $1 C$. canephora mean nuclear DNA content is $1.54 \mathrm{py}$ and can reach $1.70 \mathrm{pg}$ depending on the genotype), but the number of spceies and genotypes studied aliows a general overview of interspecitic variation in nuclear DNA content within the Coffor gonus. The extreme values are 0.95 and $1.78 \mathrm{pg}$. Arumuganathan and Earle $(199 \mathrm{l})$ and Bennett and Smith (1991) have reviewed the nuclear DNA content of a large number of species. Coffea species could be considered to have a low nuclear DNA content compared with Viscum album (152 pg). Alium cepa $132.7 \mathrm{pg}$. or Pinls carabeac (45.6 pg). Coffea DNA content is similar to species like Acacia heterophylla (1.60 pg). Beta valgaris (1.75 pg). Datucus carota $(1.19 \mathrm{pg})$, Diostorea alata $(1.47 \mathrm{pg})$. and Vigha unguialata (1.20 pg) (all data from Marie and Brown 1993). Assuming that the mean base pitir weight is $660 \mathrm{Da}$ (Sambrook et al. 1989). the niean coffee haploid genome is cstimated as 700 million base pairs.

Intra- and inter-specific variation at the same ploidy level A twofold variation in DNA content was observed at the diploid level for Coffea species and up to $10 \mathrm{j}-15 \%$ intraspecific variation. Price 1988 , has clearly shown that differences in excess of twofold to three fold are common among congeneric diploid specics. In the genus Helianthas, total DNA content varies more then fourfold among diploid species (Sim and Price 1985: Cavallini et al, 1989: Michatelson et al. 1991). Bennett 11985 ) reported that the cxtent of variation of the nuclear genome within some species may be considerable. reaching 54\% for Glvine max and $228 \%$ for Collinsiat toma. Variation. were also obsersud in some crop species like Zea mays $130 \%$ and Capsicum ammam $135 \%$. In contrast. species such as Hordcum valgare. Ticin faha. Sorghum bicolor. and Fe'slica pratensis do not exhibit such polymorphism (Laturie and Bennett 1985: Bennett and Smith 1991!. Interspecitic variations are similar to those observed in other genera, and intraspecitic variations found for Coffica species may be considered small.

\section{Interspecific variation at the polyploid level}

The calculated $1 C$ value of $C$. arablia is $1.3 \mathrm{pg}$. De Lat et al. (1987) showed that in atutopolyploid serics as in the genera Malus and Prams. the DNA content is exactly doubled. Cotfea arabica $12 n=4+1$ is supposed to be atn allotetraploid of amphiploid nrigin. so it could be the sum of two species with different genome sizes. Berthold et al, 11983) compared total cpDNA of different Coffea species and suggested that $C$. arecnioides may be a good putative progenifor. Cros at al. (1993) used chloroplastic prohes to threv that C. angonioldes. C. sp. Molininden and C. u. F chloroplast canmot be distinguished from $C$. wabliat. In the present study. beatuse of the obserted intrispecitic sariation. my hypothow concerning C. arabia linetge can bo sachuded.

\section{Coffea diploid variation according to genetic and ecogeographic origin of species}

Five of six diploid species with less than $1.5 \mathrm{pg}$ of DNA per nucleus are native to the East African biogeographic area. According to Furuta and Nishikawa (1991), evolution at a given ploidy level may be associated with a gradual increase in DNA content. Kenton (1984) noted that the more specialized species of the Gibasis linewis group contain more DNA. This author suggested that the DNA content increases during evolution. In terms of Coffed species. Leroy (1982) suggested than the center of origin of the genus is the Kenyan region. which was close to Madagascar until the Gondwanian separation during the Cretaceous period. From this area. species radiation has occurred twice: in Madagascar and in central and western Africa (Guinca-Congo region). Our data clearly indicate that species endemic in East Africa contain less DNA than species endemic in the Guinea-Congo region. Moreover, the higher DNA content is found for C. humilis. which is endemic in the west margin of the distribution area at the boundary between Cote divoire and Guinea (Berthaud 1986́). If the radiation route described by Leroy is correct. our results for African species are consistent with an increase in genone size during evolution.

In a large number of species of British flora. Grime and Mowtorth (1982) noted a correlation between large genome size and capacity for growth at low temperature. Price (1988) reported that the decrease in DNA content might be a adaptative process of a plant group from mesic to more xeric conditions. Coffea species of high nuclear DNA content are native to the evergreen forest (Guinea-Congo regisn): spccies of low content are native to dry forest (East Africa).

Price (1988) also report that total DNA content may be positively correlated with cell cycle duration. Wakamiya at al. (1993) observed positive correlations between nuclear DNA contents and growth indices. minimum seed-bearing age, and seed dimensions for 19 North American Pims: species. In contrast, strong negative correlations were observed with the lowest mean annual precipitation. Coffea sessiliflora and $C$. pactdranguchata. Which flower frequently. have very small seeds. a small number of thowers per node, and a shorter period of seed maturation. i.e. 2 months versus $7-$ 15 months for species native to western Africa $1 C$. cancphomo C. liberiat, $C$. congensis, C. hamilis and $C$. ntenophyllas (Hamon et al. 1984: Anthony 1992). If we assume that the process of sed maturation implies a constant number of coll divisions from flowering to ripening. a smaller genome size and conscquently lowered DNA s nthesis requirement could be good adaptitive features.

An apparent contradiction is noted with C. stenephylla. a Guineo-Gongolian species that litie a long period of secd maturation caround in months: Berthaud 1986 but only contain $1.35 \mathrm{pg}$ of DNA per nucleus. In fact this lou DNA content could be an adaptation to the relatively dry conditions found in the nuargin areat of the west African evergreen forest in Guinea and northern Cote d"loire. Where this spesios was found Portieres 1962: Berthad 1986 i.

\section{Relationship between DBA inntent and tertility of interspecific ho brids}

Interspecitic hybrids have hocn made i Louarn 1903 ibetineen C. comphira, C. angensis and C. librica tounea- 
Congo region) and $C$. racemosa, C. sessiliflora, and C. pseudozanguebariae (East Africa). The authour analyzed the male and female fertility of a large number of interspecific hybrids and noted that species originating from the same area are more or less interfertile (pollen viability higher than $55 \%$ ). The pollen viability of $F_{1}$ hybrids between the two groups (species from the Guinea-Congo region and species from East Africa) is below 30\%. These results can be explained by differences in genome size, which could be the result of different numbers of copies of highly repetitive sequences and deletion-duplication or polyteny of large chromosomal coding regions (Vedel and Delseny 1987).

In conclusion, the total DNA content of Coffea species is low compared with that of other angiosperms and there is an intrageneric twofold variation in genome size. These differences may correspond to genomic evolution correlated with an ecological adaptative process. The three species with a lower DNA content originated from the supposed center of origin of the genus (Kenya). This result could be an argument in favor of the increase of the DNA content during evolution in the Coffea subgenus. In addition, species adapted to xeric conditions have a lower DNA content than other species. Species that differ by more than $0.5 \mathrm{pg}$ in nuclear DNA content produce interspecific $F_{1}$ hybrids of reduced fertility.

\section{References}

Anthony, F. 1992. Les ressources génétiques des caféiers : collecte, gestion d'un conservatoire et évaluation de la diversité génétique. Série TDM 81. Presses de l'ORSTOM, Paris.

Arumuganathan, K., and Earle, D. $1991 a$. Estimation of nuclear DNA content of plants by flow cytometry. Plant Mol. Biol. Rep. 9: 119-241.

Arumuganathan, K., and Earle, D. 1991b. Nuclear DNA content of some important plant species. Plant Mol. Biol. Rep. 9: 208-218.

Bennett, M.D. 1985. Intraspecific variation in DNA amount and the nucleotypic dimension in plant genetics. In Plant genetics. Edited by M. Freeling. UCLA Symp. Mol. Cell. Biol. New Ser. 35: 283-302.

Bennett, M.D., and Smith, J.B. 1991. Nuclear DNA amounts in angiosperms. Philos. Trans. R. Soc. Lond. B Biol. Sci. 334: 309-345.

Berthaud, J. 1986. Les ressources génétiques pour l'amélioration des caféiers Africains diploïdes. Série TDM No. 188. Presses de l'ORSTOM, Paris.

Berthaud, J., and Charrier, A. 1988. Genetic resources of Coffea. In Coffee. Vol. 4. Agronomy. Edited by R.J. Clarke and R. Macrae. Elsevier Applied Science Publishers, London. pp. 1-42.

Berthou, F., Mathieu, C., and Vedel, F. 1983. Chloroplast and mitochondrial DNA variation as indicator of phylogenetic relationships in the genus Coffea L. Theor. Appl. Genet. 65: 77-84.

Bridson, D., and Verdcourt, B. 1988. Coffea. In Flora of tropical East Africa: Rubiaceae. Part 2. Edited by R.M. Polhill. A.A. Balkema, Rotterdam, The Netherlands. pp. 703-723.

Cavallini, A., Zolfino, C., Natali, L., and Cionini, G. 1989. Nuclear DNA changes within Helianthus annus
L.: origin and control mechanism. Theor. Appl. Genet. 77: $12-16$.

Charrier, A. 1978. La structure génétique des caféiers spontanés de la région Malgache (Mascarocoffea). Leurs relations avec les caféiers d'origine Africaine (Eucoffea). Mem. ORSTOM No. 87.

Chevalier, A. 1947. Les caféiers du globe.

III. Systématique des caféiers et faux cafëiers. Maladies et insectes nuisibles. In Encyclopédie biologique. P. Lechevalier, Paris.

Cros, J., Lashersmes, P., Marmey, P., Anthony, F., Hamon, S., and Charrier, A. 1993. Molecular analysis of genetic diversity and phylogenic relationships in Coffea. In Proceedings of the 15th Congress of the International Scientific Association of Coffee, June 6-11, 1993, Montpellier, France. Vol. 1. ASIC, Paris, France (Publishers). pp. 41-46.

De Laat, A.M.M., Göhde, W., and Vogelzang, M.D.C. 1987. Determination of ploidy of single plants and plant populations by flow cytometry. Plant Breeding, 99: $303-307$.

Dolezel, J. 1991. Flow cytometric analysis of nuclear DNA content in higher plants. Phytochem. Anal. 2: $143-154$.

Dolezel, J., Sgorbatti, S., and Lucretti, S. 1992. Comparison of three DNA fluorochromes for flow cytometric estimation of nuclear DNA content in plants. Physiol. Plant. 85: 625-639.

Furuta, Y., and Nishikawa, K. 1991. Variation in nuclear chromosomal DNA content and its role in evolution of plants. In Chromosome engineering in plants, Part A. Edited by P.K. Gupta and T. Tsuchiya. Elsevier Science Publishers B.V., Amsterdam, the Netherlands. pp. $71-85$.

Galbraith, D.W., Harkins, K.R., Madox, J.M., Ayres, N.M., Sharma, D.P., and Fizoozabaky, E. 1983. Rapid flow cytometric analysis of the cell cycle in intact plant tissues. Science (Washington, D.C.), 220: $1049-1051$.

Grime, J.P., and Mowforth, M.A. 1982. Variation in genome size - an ecological interpretation. Nature (London), 229: 151-153.

Hamon, S., Anthony, F., and Le Pierres, D. 1984. La variabilité génétique des caféiers de la section Mozambicoffea A. Chev. Précisions sur 2 espèces affines : C. pseudozanguebariae Bridson et C. sp. Bridson. Bull. Mus. Natl. Hist. Nat. Sect. B: Andansonia, 6: 207-223.

Kenton, A. 1984. Chromosome evolution in the Gibasis linearis group (Commelinaceae). Chromosoma, 90: $303-310$.

Laurie, D.A., and Bennet, M.D. 1985. Nuclear DNA content in the genera Zea and Sorghum. Intergeneric, interspecific and intraspecific variation. Heredity, 55: $307-313$.

Leroy, J.-F. 1982. L'origine kenyane du genre Coffea L. et la radiation des espèces à Madagascar. In Proceedings of the 10th Congress of the International and Scientific Association of Coffee, October 11-14, 1982, Salvador. ASIC, Paris, France (Publishers). pp. $413-420$. 
Louarn. J. 1993. Structure génétique des caféiers africains diploides basée sur la fertilité des hybrides interspécifiques. In Proceedings of the 15th Congress of the International Scientific Association of Coffee. June 6-11. 1993. Montpellier, France. Vol. 1. ASIC. Paris, France (Publishers). pp. 243-252.

Marie, D., and Brown, S.C. 1993. A cytometric exercise in plant DNA histograms with $2 \mathrm{C}$ values for 70 species. Biol. Cell, 78: $41-51$.

Michaelson. M.J., Price, H.J., Johnson, J.R., and Ellison. J.R. 1991. Variation of nuclear DNA content in Helianthus annuls (Asteraceae). Am. J. Bot. 78: $1238-1243$.

Portères, R. 1962. Caféiers de la république de Guinée. Cafe Cacao The, 1: 3-18.

Price, H.J. 1988. DNA content variation among higher plants. Ann. Mo. Bot. Gard. 75: 1248-1257.
Sambrook, J., Fritsch, E.F., and Maniatis, T. 1989. Molecular cloning. A laboratory manual. Vol. 3. Appendix Cl. Cold Spring Harbor Laboratory Press. Cold Spring Harbor. N.Y.

Sim. L.. and Price. H.J. 1985. Nuclear DNA content variation in Helianthus (Asteraceae). Am. J. Bot. 72: $1213-1219$.

Ulrich. I., and Ulrich. W. 1991. High-resolution flow cytometry of nuclear DNA in higher plants. Protoplasma. 165: 212-215.

Vedel, F., and Delseny, M. 1987. Repetitivity and variability of higher plant genomes. Plant Physiol. Biochem. 25: $191-210$.

Wakamiya. I., Ronald, J.N., Johnson. J.S.. and Price, H.J. 1993. Genome size and environmental factors in the genus Pinus. Am. J. Bot. 80: 1235-1241. 